\title{
Radon Concentrations Measurement in Aljouf, Saudi Arabia Using Active Detecting Method
}

\author{
Mohammed D. Alenezy ${ }^{1,2}$ \\ ${ }^{1}$ Physics Department, Faculty of Education, Al Dammam University, Al Dammam, Saudi Arabia \\ ${ }^{2}$ Physics Department, Faculty of Science, Aljouf University, Aljouf, Saudi Arabia \\ Email: mdahawy@gmail.com
}

Received 25 May 2014; revised 2 July 2014; accepted 11 July 2014

Copyright (C) 2014 by author and Scientific Research Publishing Inc.

This work is licensed under the Creative Commons Attribution International License (CC BY).

http://creativecommons.org/licenses/by/4.0/

(c) (i) Open Access

\begin{abstract}
Rn-222 is the most important source of natural radiation and is responsible for approximately half of the received dose from all sources. Most of this dose is from inhalation of the Rn-222 progeny, especially in closed ares. Portable alpha particle detector, RAD7 was used for Rn-222 measurements inside the main campus of Aljouf University at Saudi Arabia in order to estimate the effective dose to the occupants from ${ }^{222} \mathrm{Rn}$ and its progeny. The values of annual effective doses for radon inhalation by the inhabitants were found to vary in the range $0.08-0.80 \mathrm{mSv} / \mathrm{y}$, with a mean of $0.4 \mathrm{mSv} / \mathrm{y}$. These results are lower than the value $1 \mathrm{mSv} / \mathrm{y}$ recommended by ICRP, 1990. The variation of dose relationship from indoor radon in lung tissue is calculated and tabulated. In addition to environmental value of the present survey, the results are considered to be essential in analyzing any data for future activities in this field.
\end{abstract}

\section{Keywords}

Aljouf, RAD7, ${ }^{222}$ Rn, Annual Effective Dose

\section{Introduction}

Radon is a naturally occurring radioactive, odorless, colorless gas that is continuously released by natural sources, such as geological formations in soil and construction materials. Radon and its daughters are formed during the radioactive decays of uranium and thorium, in the Earth's crust, to lead, of which the latter is the stable product of the decay processes. The various half-lives of the radio nuclides are very important in determining the relative contributions of the decay series to bronchial dose . The half-life of ${ }^{222} \mathrm{Rn}$ is $3.824 \mathrm{~d}$. It has four 
short-lived decay products: ${ }^{218} \mathrm{Po}(3.05 \mathrm{~min}),{ }^{214} \mathrm{~Pb}(26.8 \mathrm{~min}),{ }^{214} \mathrm{Bi}(19.9 \mathrm{~min})$, and ${ }^{214} \mathrm{Po}(164 \mu \mathrm{s})$. Both polonium isotopes are alpha-emitters. The relatively short half-life of ${ }^{220} \mathrm{Rn}(55.6 \mathrm{~s})$ means that it does not have much time to travel from its production site to the immediate environment of human beings. The relatively long halflife of one of its decay products, ${ }^{212} \mathrm{~Pb}(10.6 \mathrm{~h})$, allows this isotope time to deposit on surfaces or migrate away from its source before producing the important alpha-emitter ${ }^{212} \mathrm{Bi}(60.6 \mathrm{~min})$. The relative concentrations of the various radionuclides in the decay series are also strongly affected by dynamic processes, including the attachment of the decay products to aerosol particles and their subsequent deposition on room surfaces or the ground as well as air movement in general. The fraction of radon progeny in an ultrafine mode $(0.5-2 \mathrm{~nm})$, not attached to ambient aerosol particles, is known as the unattached fraction [1].

The inhalation of radon ${ }^{222} \mathrm{Rn}$ and its radioactive daughters, even for people exposed to low radon levels that may be found in residential buildings [2], increases the chance of developing lung cancer [3]. When inhaled, radon particles carrying daughters enter and stick onto the bronchial air passages, irradiating and damaging the surrounding cells. Based on national and worldwide investigations, several agencies have concluded that radon is a known cancer causing agent in humans and is the second most common cause of lung, skin, and leukemia cancers after smoking [4]. Radon enters the body system during inhalation, which results in an increase in the exposure dose that can result in the development of lung cancer. Radon $\left({ }^{222} \mathrm{Rn}\right)$ and its progeny in air are the most important contributors to human exposure from all natural radiation sources [5]. ${ }^{222} \mathrm{Rn}$ is regarded as a risk factor that contributes to the global burden of disease and is the second biggest cause of lung cancer after tobacco smoking. In general, residential ${ }^{222} \mathrm{Rn}$ is regulated by a ${ }^{222} \mathrm{Rn}$ concentration action level between 200 and $600 \mathrm{~Bq} \cdot \mathrm{m}^{-3}$ based on ICRP recommendations [6]. Recently, however, an increase in lung cancer risk has been observed even with exposure levels below $200 \mathrm{~Bq} \cdot \mathrm{m}^{-3}$. In view of such scientific data, [7] proposed a reference level of $100 \mathrm{~Bq} / \mathrm{m}^{3}$ to minimize health hazards due to indoor ${ }^{222} \mathrm{Rn}$ exposure. Researches carried out in recent decade's show, under normal conditions, ingestion of natural radioactive gas radon ${ }^{222} \mathrm{Rn}$ and its decay products. Long term exposures to radon via inhalation in closed rooms or caves or open air saturated with radon gas are the cause of about $10 \%$ of all deaths from lung cancer [8]. Studied also related to radon in kidney and malignant melanoma cancer have been reported [9].

In Saudi Arabia radon concentrations have been considered by the scientists as well and measured in several parts in the Kingdom. [10] published radon measurements in a total of 19 Khafji cities and discuss the first survey of this type in Saudi Arabia. [11] monitored radon in 1200 houses in four cities Hafr Al-Batin, Khafji, Madina and Taif. [12] monitored radon in 2700 house and 98 school nine cities in Saudi Arabia seven in the eastern province Dammam, Abqaiq, Al Ahsa, Hafr Al Batin, Khafji, Qatif, and Khobar and two in western province Madina and Taif. The lowest average radon concentration $8 \mathrm{~Bq} \cdot \mathrm{m}^{-3}$ was found in Ahsa while the highest average concentration $40 \mathrm{~Bq} \cdot \mathrm{m}^{-3}$ was found in Khafji. There are also other studies dealing with radon in Saudi Arabia cities [13]. In addition there are academic programs in Saudi universities concerened with the concentration of radon levels in areas in the Kingdom [14]-[18]. More investigations and surveys are still needed and are being carried out to add new building types and locations to the data base, and to review existing data using different instruments and methods.

A national project was established [19]. ${ }^{222} \mathrm{Rn}$ concentration was measured at 12 locations in the Aljouf province, using RAD7. In each location three different depths were taken for soil gas measurements. The current study investigated the distribution of indoor radon concentrations in the main campus of Aljouf University in order to estimate the effective dose to the public from ${ }^{222} \mathrm{Rn}$ and its progeny ${ }^{222} \mathrm{Rn}$ concentrations in dwellings.

\section{The Study Location and Measurement Sites}

Aljouf province is located between 42, 37 longitude and 32, 29 latitude in the northwestern part of Saudi Arabia stretching out in the east from Hail region westward to the border of Jordan and from the region of Tabuk in the south until northern border region in the west Figure 1. The surface are of the land of the province is low and starts declining from the east to the west with the surface elevation varying between 1200 meters to 300 meters above the sea level. Aljouf province is occupying an area of 258,000 square meters of the land in the Kingdom, and has a population of 290,000 people spread over the provinces and cities and villages of the region centers spread throughout the area. Its capital city is Sakaka, which is inhabited by approximately $49 \%$ of the region's total population. Sakaka has a Desert climate with hot \& dry summers, and cold winters. Aljouf University was established in 2005. Since the establishment of the university, it has experienced a remarkable growth in enroll- 


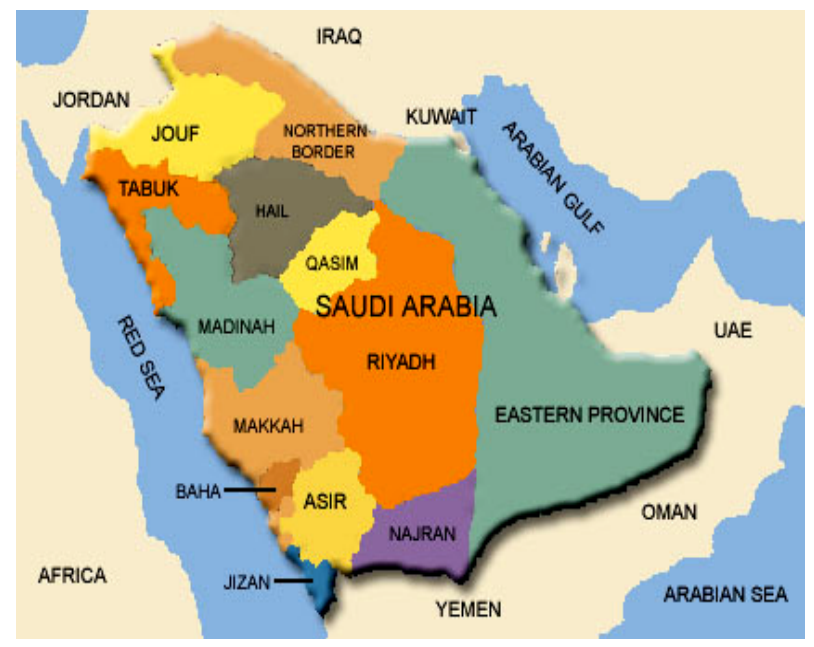

Figure 1. Map shows the study area, Aljouf province in northwestern part of Saudi Arabia.

ment and a significant expansion of faculty and its administrative staff. At present the university encompasses 19 colleges both for male and female students. Aljouf University is located in the center of the Aljouf region, 3 $\mathrm{km}$ south of Aljouf regional airport. The present work deals with the measurement of radon concentration in some offices and laboratories of the Main Campus of Aljouf University by using RAD7 Figure 2 [20] in order to see if the students, teachers, employees are at any risk from radon related health hazards. Moreover, mean annual effective dose due to radon will also calculate and compared with the maximum permissible level of the world recommended value. With this paper we also aim to create interest and increase public awareness about the radon hazard in the community.

\section{Experimental Method}

\subsection{Radon Measurement Instrument RAD7}

In the interior of the measurement instrument RAD7 from Durridge Company we find a hemisphere with a silicon solid-state detector. A representation of the measurement chamber with the detector is shown in Figure 3 [21]. Through the filter the sample air is sucked in by the pump and reaches the detector chamber. There a high voltage of 2000 to $2500 \mathrm{~V}$ between the detector and the hemisphere accelerates the positively ionized particles towards the detector. If a radon nucleus decays in the chamber into a positively ionized polonium- 218 this particle will be accelerated towards the detector. On the surface of the detector the short lived ${ }^{218}$ Po decays and the $\alpha$ radiation with a characteristic energy is emitted to the detector. The detector produces a signal with 50 per cent probability. This signal is intensified electronically and transformed into a digital signal. The microprocessor stores the energy level of the signal and produces the spectrum.

After the preparations of the measurement we can pump radon containing air into the RAD7. After a short time we can see some counts in the energy interval A, which is the energy interval of the $\alpha$ decay of ${ }^{218} \mathrm{Po}$. Usually the counting rate increases in the first five minutes, because in this period of time the amount of positive ionized ${ }^{218}$ Po nuclei increases until it reaches a constant level on the detector. After 20 minutes the secular equilibrium state between ${ }^{218} \mathrm{Po}$ and ${ }^{222} \mathrm{Rn}$ is reached, the activity of the daughter nucleus is similar to the activity of the mother nucleus. At this time almost all counts can be found in the energy level A, which you can see in Figure 4. After a period of time we find that the counts per time in A are constant, but the overall counting rate increase. These new counts occur at the energy level $\mathrm{C}$ of the spectrum. They originate from the decay of ${ }^{214} \mathrm{Po}$ which reaches its equilibrium state after 3 hours. In the full equilibrium state the height of both peaks is almost equal, as shown in Figure 4.

\subsection{Work Principle of RAD7}

The internal cell of RAD7 is a hemisphere with volume 0.7 liter. An ion-implanted, planar, and silicon alpha 


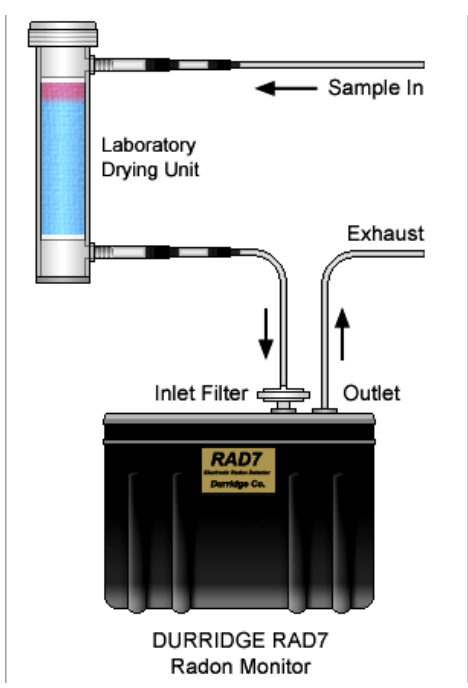

Figure 2. As air is drawn by pump in the humidity exchanger, the sphere from which the air has been pumped grows in size.

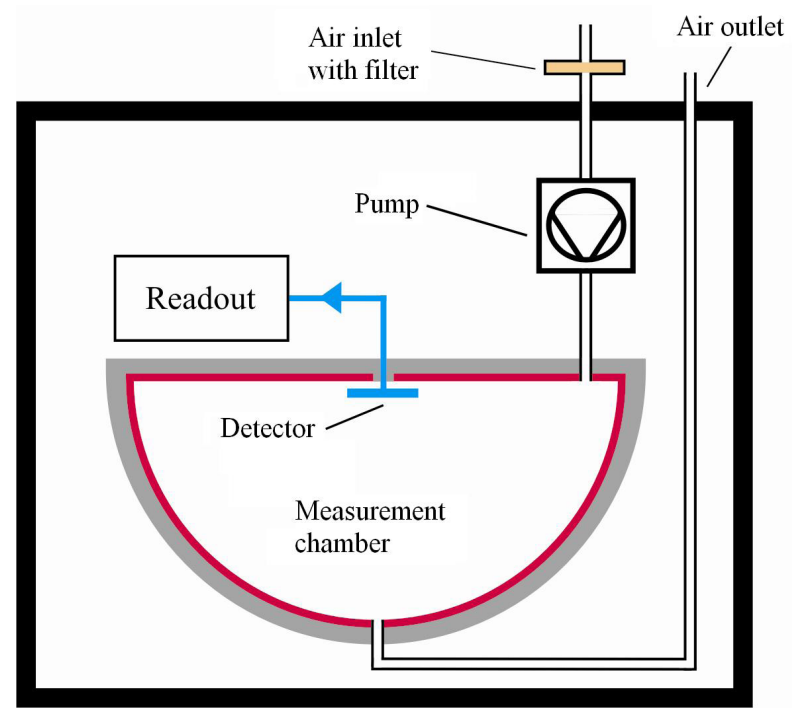

Figure 3. Measurement chamber of the RAD7.

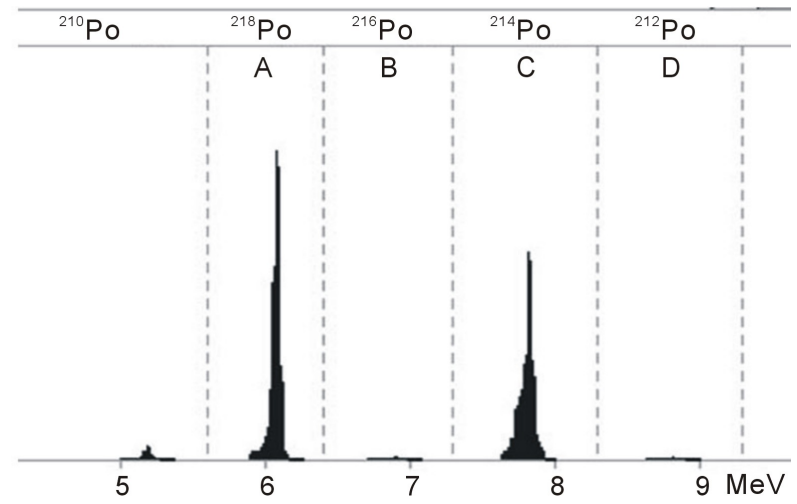

Figure 4. RAD7 alpha spectrum- ${ }^{218} \mathrm{Po}$ (window A) and ${ }^{214} \mathrm{Po}$ (window $\mathrm{C}$ ). 
detector is at the center of the hemisphere. The high voltage power circuit charges the inside conductor to a potential of $2000-2500 \mathrm{~V}$, relative to the detector, creating an electric field throughout the volume of the cell. When the radon and thoron daughters, deposited on the surface of the detector, decay, they emit alpha particles of characteristic energy directly into the solid state detector. The RAD7's microprocessor picks up the signal and stores it according to the energy of the particle. The accumulations of many signals result in a spectrum. The sniff mode should be used when following the rapid changes in radon concentration. In this mode, the RAD7 achieves rapid responses to changing radon levels by focusing on the $3 \mathrm{~min}{ }^{218} \mathrm{Po}$ alpha peak. Using the internal pump, the RAD7 draws air from the environment through the desiccant and inlet filter into the measurement chamber. The air will then return to the environment [22]. The radon concentration in the internal cell of RAD7 is determined by the following differential equation:

$$
\begin{gathered}
\frac{\mathrm{d} C(t)}{\mathrm{d} t}=-\lambda C(t), \\
\frac{\mathrm{d} C_{\mathrm{Po}}(t)}{\mathrm{d} C}=\lambda_{\mathrm{Po}} C(t)-\lambda_{\mathrm{Po}_{\mathrm{o}}} C_{\mathrm{Po}_{\mathrm{o}}}(t)
\end{gathered}
$$

where $C(t)$ is the radon concentration in the internal cell of RAD7, $\lambda$ is the decay constant of radon, $C_{p o}(t)$ is ${ }^{218} \mathrm{Po}$ concentration, and $\lambda_{\mathrm{Po}}$ is ${ }^{218} \mathrm{Po}$ decay constant and equals to $0.0037 \mathrm{~s}^{-1}$.

After a certain time of pumping, the radon concentration in internal cell of RAD7 equals to that of the environment $C_{0}$. Equation (2) can be rewritten as

$$
\mathrm{d} C_{\mathrm{Po}}(t) \mathrm{d} t=\lambda_{\mathrm{Po}} C_{0}-\lambda_{\mathrm{Po}} C_{\mathrm{Po}}(t)
$$

The initial condition is

$$
C_{\mathrm{Po}}(0)=0
$$

The solution of Equation (3) is

$$
C_{\mathrm{Po}}(t)=C_{0}\left(1-e^{-\lambda_{\mathrm{Po}} t}\right)
$$

If the time is much longer than the half-life of ${ }^{218} \mathrm{Po}$, Equation (5) can be rewritten as [23]

$$
C_{\mathrm{Po}}(t)=C_{0}
$$

Radon concentration can be obtained from Equation (6), and this is the measurement principle of RAD7.

RAD7 was connected with tubing and desiccant $\left(\mathrm{CaSO}_{4}\right)$ to absorb the moisture Figure 2. The resulting air-gas radon concentration $\left(\mathrm{Bq} \cdot \mathrm{m}^{-3}\right)$ was recorded for 20 minute cycle along with relative humidity $(\%)$ and ambient temperature $\left({ }^{\circ} \mathrm{C}\right)$. An accumulation chamber with a height of $7.5 \mathrm{~cm}$, diameter of $20 \mathrm{~cm}$ and volume of $2.357 \mathrm{~m}^{3}$ was used to measure radon exhalation rate from the air. The uniformity in flow rate of radon concentration was maintained using an auto flow pump. The thoron discriminator was used to eliminate thoron gas and radon progenies. The resulting radon concentration $\left(\mathrm{Bq} \cdot \mathrm{m}^{-3}\right)$, relative humidity $(\%)$, and temperature $\left({ }^{\circ} \mathrm{C}\right)$ were recorded and stored in the RAD7.

\section{Results and Discussion}

In our study thirty locations in Aljouf University have been selected to achieve this study. Table 1 illustrated the concentrated of radon in this locations measured by $\mathrm{Bq} / \mathrm{m}^{3}$. The results show that the higher activity of radon was (31) $\mathrm{Bq} / \mathrm{m}^{3}$ in Main Hall Faculty of Engineering and physical therapy Lab, Faculty of Applied and Medical Science, low activity was (3) $\mathrm{Bq} / \mathrm{m}^{3}$ in Physical chem. Lab, Faculty of Science. With mean value $11.7 \mathrm{~Bq} / \mathrm{m}^{3}$. Figure 5 shows percentage contribution to average concentration ${ }^{222}$ Radon by location. Aljouf University with indoor surveys in dwelling reported worldwide is given in Table 2. It is clear that the detected concentration values of ${ }^{222} \mathrm{Rn}$ in the main campus of Aljouf University are lower than those values reported in other worldwide locations, see Table 2 and also lower than the median values $46 \mathrm{~Bq} \cdot \mathrm{m}^{-3}$, reported by [5]. On the other hand, it was found that the detected concentration values of ${ }^{222} \mathrm{Rn}$ in the main campus of Aljouf University are in agreement with those reported in some other countries such as Egypt, Japan, Australia, Kuwait and Cyprus.

The variation in the indoor radon concentration due to many reasons such as the different ventilation rate and 


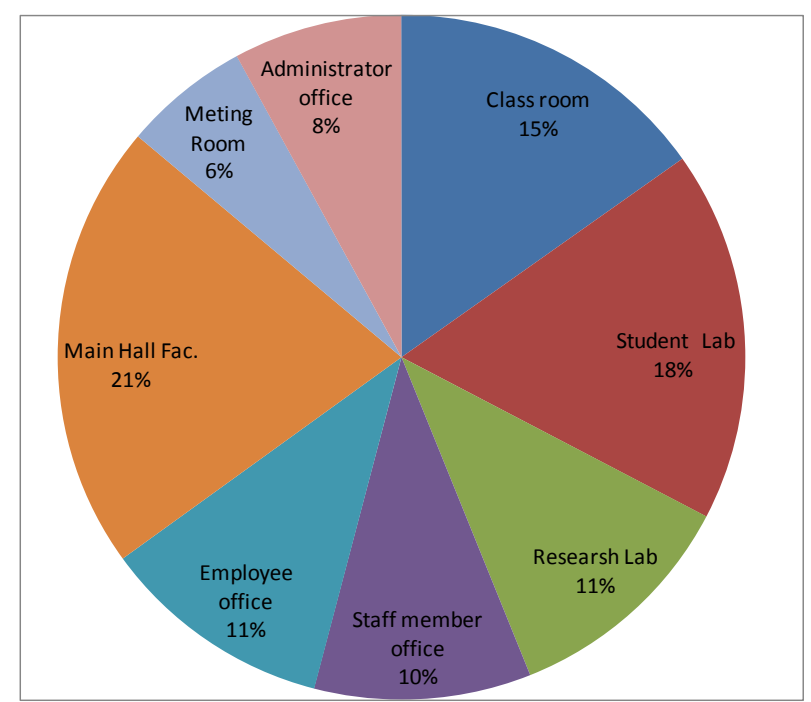

Figure 5. Percentage contribution to average concentration Radon-222 by location.

Table 1. Indoor radon concentrations, EEC and dose relationships from air in the main campus of Aljouf university.

\begin{tabular}{|c|c|c|c|c|c|}
\hline Location & $\begin{array}{l}\text { Radon-222 } \\
\left(\mathrm{Bq} / \mathrm{m}^{3}\right)\end{array}$ & $\begin{array}{c}\text { EEC } \\
\left(\mathrm{Bq} \cdot \mathrm{h} / \mathrm{m}^{3}\right)\end{array}$ & $\begin{array}{l}\mathrm{D}_{\text {soft tissues }} \\
(\mathrm{nGy} / \mathrm{h})\end{array}$ & $\begin{array}{c}\mathrm{D}_{\text {Lung }} \\
(\mathrm{nGy} / \mathrm{h})\end{array}$ & $\begin{array}{c}\text { Annual effective } \\
\text { dose }(\mathrm{mSv} / \mathrm{y})\end{array}$ \\
\hline Meeting Room S104 & 4.7 & 2.11 & 0.024 & 0.188 & 0.118 \\
\hline Class room F55 & 4.7 & 2.11 & 0.024 & 0.188 & 0.118 \\
\hline Modern physics Student Lab G61 & 3.2 & 1.44 & 0.016 & 0.128 & 0.081 \\
\hline Electromagnetic Student Lab G59 & 7.9 & 3.56 & 0.040 & 0.316 & 0.199 \\
\hline Optic Student Lab G60 & 9.5 & 4.27 & 0.048 & 0.38 & 0.239 \\
\hline Class room F73 & 9.5 & 4.27 & 0.048 & 0.38 & 0.239 \\
\hline Radiation physics research Lab G 14 & 11.5 & 5.175 & 0.058 & 0.46 & 0.289 \\
\hline Staff member office (1) & 4.2 & 1.89 & 0.021 & 0.168 & 0.106 \\
\hline Staff member office (2) & 9 & 4.1 & 0.045 & 0.36 & 0.227 \\
\hline Nuclear physics Student Lab G67 & 16.9 & 7.61 & 0.085 & 0.676 & 0.426 \\
\hline Main Hall Faculty of Science & 12.7 & 5.72 & 0.064 & 0.508 & 0.320 \\
\hline Employee office 1 & 4.2 & 1.89 & 0.021 & 0.168 & 0.106 \\
\hline Employee office 2 & 6 & 2.7 & 0.030 & 0.24 & 0.151 \\
\hline Employee office 3 & 15.8 & 7.11 & 0.079 & 0.632 & 0.398 \\
\hline Computer lab in Fac. of Engineering & 15.8 & 7.11 & 0.079 & 0.632 & 0.398 \\
\hline Class room $\mathrm{K} 6$ & 19 & 8.55 & 0.095 & 0.76 & 0.479 \\
\hline Electronic Student Lab G68 & 19 & 8.55 & 0.095 & 0.76 & 0.479 \\
\hline Zoology student Lab G107 & 13 & 5.85 & 0.065 & 0.52 & 0.327 \\
\hline Botany student Lab G113 & 12 & 5.4 & 0.060 & 0.48 & 0.302 \\
\hline Physical chem. Lab G123 & 3 & 1.35 & 0.015 & 0.12 & 0.076 \\
\hline X-Ray reading Room G151 & 15.8 & 7.11 & 0.079 & 0.632 & 0.398 \\
\hline physical therapy Lab G67 & 31.6 & 14.22 & 0.158 & 1.26 & 0.796 \\
\hline Class room F216 & 15 & 6.75 & 0.075 & 0.61 & 0.378 \\
\hline Staff member office (3) & 16 & 7.2 & 0.080 & 0.64 & 0.403 \\
\hline Nursing Fundamental Lab G83 & 19 & 8.55 & 0.095 & 0.76 & 0.479 \\
\hline Main Hall Fac. of App. and Med.Scie. & 6 & 2.7 & 0.030 & 0.24 & 0.1512 \\
\hline Main Hall Fac. of Engineering & 31.6 & 14.22 & 0.158 & 1.264 & 0.796 \\
\hline Research Lab G77 & 6.3 & 2.84 & 0.032 & 0.252 & 0.159 \\
\hline Administrator office & 6.3 & 2.84 & 0.032 & 0.252 & 0.159 \\
\hline Staff member office (4) & 3.1 & 1.40 & 0.016 & 0.125 & 0.079 \\
\hline
\end{tabular}


Table 2. Arithmetic mean and maximum values of radon concentrations in dwelling determined in indoor surveys.

\begin{tabular}{|c|c|c|c|c|}
\hline \multirow{2}{*}{ Region } & \multirow{2}{*}{ Country } & \multicolumn{2}{|c|}{ Radon $\mathrm{Bq} / \mathrm{m}^{3}$} & \multirow{2}{*}{ Reference } \\
\hline & & Mean & Max. & \\
\hline \multirow{4}{*}{ West Asia } & Aljouf, Saudi Arabia & 10 & 31 & This work \\
\hline & Syria & 44 & 520 & {$[30]$} \\
\hline & Kuwait & 14 & 120 & {$[31]$} \\
\hline & Iran & 82 & 3070 & [32] \\
\hline \multirow[t]{2}{*}{ Africa } & Algeria & 30 & 140 & {$[33]$} \\
\hline & Egypt & 9 & 24 & {$[34]$} \\
\hline \multirow[t]{4}{*}{ America } & Canada & 34 & 1750 & [35] \\
\hline & United State & 46 & 1750 & [36] \\
\hline & Argentina & 37 & 211 & [37] \\
\hline & Chile & 25 & 86 & [38] \\
\hline \multirow[t]{4}{*}{ East Asia } & China & 24 & 380 & [39] \\
\hline & Hong Kong & 41 & 140 & [40] \\
\hline & India & 57 & 210 & [41] \\
\hline & Japan & 10 & 310 & [42] \\
\hline \multirow[t]{3}{*}{ North Europe } & Estonia & 120 & 1390 & [43] \\
\hline & Finland & 120 & 20,000 & [44] \\
\hline & Sweden & 108 & 85,000 & {$[45]$} \\
\hline \multirow[t]{3}{*}{ West Europe } & Austria & 48 & 190 & [1] \\
\hline & Switzerland & 70 & 10,000 & [3] \\
\hline & United kingdom & 20 & 10,000 & {$[46]$} \\
\hline \multirow[t]{3}{*}{ South Europe } & Cyprus & 7 & 78 & [47] \\
\hline & Italy & 75 & 1040 & [48] \\
\hline & Portugal & 62 & 2700 & [49] \\
\hline \multirow[t]{3}{*}{ Eastern Europe } & Czech Republic & 140 & 20,000 & {$[50]$} \\
\hline & Hungary & 107 & 1990 & [51] \\
\hline & Poland & 41 & 432 & {$[52]$} \\
\hline \multirow[t]{3}{*}{ Oceania } & Australia & 11 & 420 & [53] \\
\hline & New Zealand & 20 & 90 & [54] \\
\hline & & 46 & 480 & [5] \\
\hline
\end{tabular}

nature of the building materials, etc. The walls of all class room, student labs, research labs, offices and main halls are painting with paint covering material; the flours of all offices are covered by carpets. We noted that, moreover detected radon concentration in the rooms of the ground floor is higher than for the other floors above the ground floor. This could be attributed to the fact that the radon is heavy gas and cannot go up to higher floors. It is widely agreed that the principal source of ${ }^{222} \mathrm{Rn}$ in houses is the soil gas in the surroundings, but it could be reduced by a high ventilation rate. Adequate supply of outside air, typically delivered through the air conditioning system, is necessary in any office environment to dilute indoor radon concentrations because less ventilation allows radon to build up.

No level of radon is considered safe. In fact, many countries set their national exposure levels based on their own studies. The American Environmental Protection Agency [17] limits radon action level of $148 \mathrm{~Bq} \cdot \mathrm{m}^{-3}$. This reference represents the acceptable indoor radon level in order to limit the risk to individuals and alert them when action should be taken. In Europe, the reference level varies depending on the age of the building. Some European countries have more than one reference level, but in general it does not exceed $400 \mathrm{~Bq} \cdot \mathrm{m}^{-3}$. The Commission of the European Communities [24] has recommended two action levels, $200 \mathrm{~Bq} \cdot \mathrm{m}^{-3}$ for new homes and $400 \mathrm{~Bq} \cdot \mathrm{m}^{-3}$ for old and existing homes. In the meanwhile, some countries that have not determined a national reference level, such as Saudi Arabia, have adopted WHO action reference levels of $100 \mathrm{~Bq} \cdot \mathrm{m}^{-3}$ to minimize health hazards due to indoor radon exposure [4]. 


\section{Estimate of the Radon Exposure and Radiation Hazards}

When exposure to radon (and radon progeny) is to be compared to the exposure from other radiation sources, it is necessary to estimate the effective dose per unit radon gas exposure. In the past this has predominantly been done by using the dosimetric evaluation of the absorbed dose to basal cells of the bronchial epithelium and applying the ICRP convention for calculating effective dose (effective dose equivalent). The indoor radon concentration is expressed in terms of equilibrium-equivalent radon concentration $\left(E E C_{\mathrm{Rn}}\right)$ by using the following relation:

$$
E E C_{\mathrm{Rn}}=F \times A_{\mathrm{Rn}}
$$

where $F$ is the equilibrium factor $(F=0.45)$ and $A_{R N}$ is the measured indoor radon activity. The equivalent dose received by bronchial pulmonary regions of human lungs has been calculated using a conversion factor $1.0 \times$ $10^{-5} \mathrm{mSv}$ per $\mathrm{Bq} \cdot \mathrm{h} / \mathrm{m}^{3}$ [25]. Because of their different physical properties, radon gas and radon decay products are considered separately. Inhaled radon, being a noble gas, is constantly present in the air volume of the lungs at the concentration in air

$\left(X_{\text {RnAir }}\right)$ and is partly dissolved in soft tissues. Taking the solubility factor for soft tissues to be 0.4 and assuming that the short-lived decay products decay in the same tissue as radon gas, the following relationship for soft tissues other than the lungs was derived [26] [27].

$$
\dot{D}_{\text {Soft tissue }}\left(\mathrm{nGyh}^{-1}\right)=0.005 x_{\mathrm{RnAir}}\left(\mathrm{Bq} \cdot \mathrm{m}^{-3}\right)
$$

In the case of the lungs, in addition to the dissolved radon, the radon content of air in the lungs must be taken into account [28]. Assuming the air volume in the lungs to be $3.2 \times 10^{-3} \mathrm{~m}^{3}$ for the "Reference Man" and assuming further that the short-lived decay products will stay in the lungs, the dose rate due to alpha-radiation was determined as [26].

$$
\dot{D}_{\text {lung }}\left(\mathrm{nGyh}^{-1}\right)=0.04 x_{\mathrm{RnAir}}\left(\mathrm{Bq} \cdot \mathrm{m}^{-3}\right)
$$

The annual average effective dose for indoor radon is calculated using parameters introduced in report by [5]

$$
E_{\mathrm{Rn}}\left(\mathrm{nSvy}^{-1}\right)=C_{\mathrm{Rn}}\left(\mathrm{Bq} \cdot \mathrm{m}^{-3}\right) \times 0.4 \times 7000\left(\mathrm{hy}^{-1}\right) \times 9 n S v\left(\mathrm{~Bq} \cdot \mathrm{m}^{-3} \cdot \mathrm{h}\right)^{-1}
$$

where $C_{\mathrm{Rn}}$ is the arithmetic mean radon concentration in the units of $\mathrm{Bq} \cdot \mathrm{m}^{-3}$, the typical value of 0.4 was used as the equilibrium factor for radon indoors, a recommended value of $9 n S v\left(\mathrm{~Bq} \cdot \mathrm{m}^{-3} \cdot \mathrm{h}\right)^{-1}$ was used to convert radon equilibrium-equivalent concentration (EEC) to the effective dose, and an $80 \%$ home occupancy time, i.e., 7000 $\mathrm{h}$ per year, was assumed. Table 1 and Figure 6 shows variation of dose relationship from radon measurements from indoor air in the main campus of Aljouf University. The annual effective dose ranged between $0.12-1.26$ $\mathrm{mSv} / \mathrm{y}$, with a mean value $0.4 \mathrm{mSv} / \mathrm{y}$. The International Commission on Radiation Protection (ICRP) in its pub-

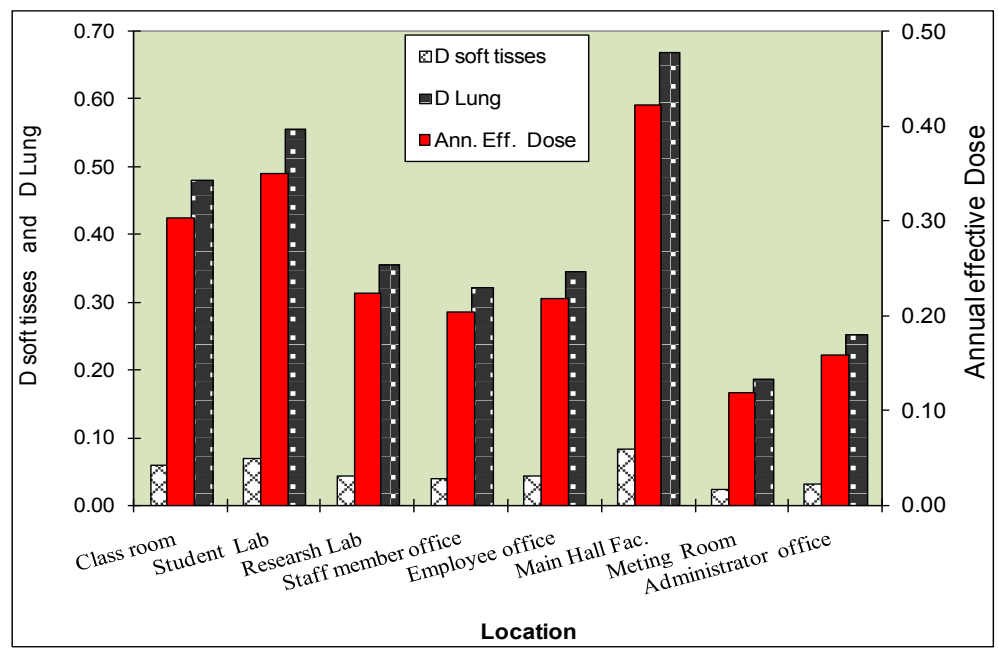

Figure 6. Average values of $\mathrm{D}_{\text {soft tissues, }} \mathrm{D}_{\text {Lung }}$ and annual effective dose by location in main campus of Aljouf University, KSA. 
lication No. 65 [6] has recommended that remedial action against radon is always justified above a continued effective dose of $10 \mathrm{mSv} \cdot \mathrm{y}^{-1}$ while a reference level within the range $3 \mathrm{mSv} \cdot \mathrm{y}^{-1}$ to $10 \mathrm{mSv} \cdot \mathrm{y}^{-1}$ has been proposed.

\section{Conclusion}

The most important radon isotope from a health viewpoint is Rn-222. Its decay products, especially ${ }^{218} \mathrm{Po}$ and ${ }^{214} \mathrm{Po}$, can have a pronounced adverse effect on lung tissues, leading to lung cancer in many cases. Radon entry into dwellings usually occurs through cracks, joints, pipe fittings in walls, loose sealants or caulking around windows, and so on. Based on the portable device RAD7, Rn-222 was measured in air inside the main campus of Aljouf University at Saudi Arabia. Radon levels ranged from 3 to $31 \mathrm{~Bq} \cdot \mathrm{m}^{-3}$, with a mean value of 11.7 $\mathrm{Bq} \cdot \mathrm{m}^{-3}$, the results were below the action level recommended by WHO of $100 \mathrm{~Bq} / \mathrm{m}^{3}$. Radon concentrations were higher in locations with no ventilation systems and were relatively lower in well ventilated locations. The annual effective dose ranged between $0.12-0.26 \mathrm{mSv} / \mathrm{y}$, with a mean value $0.4 \mathrm{mSv} / \mathrm{y}$. These results are lower than the value $1 \mathrm{mSv} / \mathrm{y}$ recommended by [9] [29]. On the basis of the current results, we may conclude that in main campus of Aljouf University at Saudi Arabia, the levels of indoor radon are well within acceptable values.

\section{References}

[1] Steinhäusler, F., Hofmann, W., Pohl, E., et al. (1980) Local and Temporal Distribution Pattern of Radon and Daughters in Anurban Environment and Determination of Organ-Dose Frequency Distributions with Demoscopical Methods. In: Gesell, T.F. and Lowder, W.M., Eds., Natural Radiation Environment III, US Department of Energy Report CONF780422, Washington, DC, 1145-1162.

[2] Sohrabi, M. and Solaymanian, A.R. (1988) Indoor Radon Level Measurements in Iran Using AEOI Passive Dosimeters. Proceedings of the 7th International Congress of the International Radiation Protection Association, 1, Pergamon Press, Sydney, 242-245.

[3] Surbeck, H. and Völkle, H. (1991) Radon in Switzerland. International Symposium on Radon and Radon Reduction Technology, 3, VI-3.

[4] Alghamdi, A.S. and Aleissa, K.A. (2014) Influences on Indoor Radon Concentrations in Riyadh, Saudi Arabia. Radian measure, 62, 35-40. http://dx.doi.org/10.1016/j.radmeas.2014.01.010

[5] United Nations Scientific Committee on the Effects of Atomic Radiation (2000) Annex B. UNSCEAR Report to the General Assembly. 1, UN, New York.

[6] ICRP International Commission on Radiological Protection (1993) Protection against Radon-222 at Home and at Work 23. Pergamon Press, Oxford.

[7] World Health Organization (2009) WHO Handbook on Indoor Radon: A Public Health Perspective. WHO Press, Geneva.

[8] Truta-Popa, L.A., Hofmann, W. and Cosma, C. (2011) Prediction of Lung Cancer Risk for Radon Exposures Based on Cellular Alpha particle Hits. Radiation Protection Dosometry, 145, 218-223.

[9] Hasan, A.K., Subber, AR.H. and Shaltakh, A.R. (2011) Measurement of Radon Concentration in Soil Gas Using RAD7 in the Environs of Al-Najaf Al-Ashraf City-Iraq. Advances in Applied Science Research, 2, 273-278.

[10] Abu-Jarad, F. and Al-Jarallah, M.I. (1986) Radon in Saudi Arabia. Radiation Protection Dosimetry, 14, $243-249$.

[11] Abu-Jarad, F., Fazal-ur-Rehman, Al-Jarallah, M.I. and Al-Shukri, A. (2003) Indoor Radon Survey in Dwellings of Nine Cities of the Eastern and the Western Provinces of Saudi Arabia. Radiation Protection Dosimetry, 106, $227-232$.

[12] Al-Jar Allah, M.I and Fazal-ur-Rehman, Abu-Jarad, F. and Al-Shukri, A. (2003) Indoor Radon Measurement in Dwellings of Four Saudi Arabian Cities. Radiation Measurements, 36, 445-448. http://dx.doi.org/10.1016/S1350-4487(03)00168-9

[13] Al-Jar Allah, M.I. and Fazal-ur-Rehman (2005) Anomalous Indoor Radon Concentration in a Dwelling in Qatif City, Saudi Arabia. Radiation Protection Dosimetry, 117, 408-413. http://dx.doi.org/10.1093/rpd/nci307

[14] Alenezy, M.D. (2002) A Seasonal Study for the Determination of Radon Concentration in Different Areas in Riyadh city in Saudi Arabia. M.Sc. Thesis, King Saud Uinversity, Riyadh.

[15] Al-Yami, S.H. (2008) Measurement of Radon Concentration in Housed in Najran Region, Saudi Arabia. M.Sc. Thesis, King Saud Uinversity, Riyadh.

[16] Alharbi, W.R. and Abbady, A.G.E. (2013) Radon Concentrations in Soil and the Extent of Their Impact on the Environment from Al-Qaseem. Natural Science, 5, 93-98. 
[17] Garawi M.S., Baig, M.R. and Alenezy, M.D. (2004) Indoor Radon Distribution inside Different Rooms of Residential Buildings in Riyadh, Saudi Arabia. Science International (Lahore), 6, 18-82.

[18] Alenezy, M.D. (1997) A Seasonal Calculation of the Radon Concentration in Riyadh Areas Using Solid State Nuclear Track Detector (SSNTD). Master Thesis, King Saud University, Riyadh.

[19] Abbady, A.G.E. and Alenezy, M.D. (2014) Measurement of Radon Concentrations in Soil Using RAD7 Detector from Aljouf. 7th international Conference for Development and the Environment in the Arab World, Asuit University, Cairo, 43-51.

[20] DURRIDGE (2012) RAD7 RADON DETECTOR User Manual. DURRIDGE Company Inc., Boston. www.durridge.com

[21] Lorenz, S., Kaudse, T. and Aeschbach-Hertig, W. (2011) F50/51 Limnophysics Version.

[22] Tan, Y. and Xiao, D.T. (2011) A Novel Algorithm for Quick and Continuous Tracing the Change of Radon Concentration in Environment. Review of Scientific Instruments, 82, Article ID: 043503. http://dx.doi.org/10.1063/1.3572271

[23] Tokonami, S., Takahashi, H., Kobayashi, Y., Zhuo, W. and Hulber, E. (2005) Up-to-Date Radon-Thoron Discriminative Detector for a Large Scale Survey. Review of Scientific Instruments, 76, Article ID: 113505. http://dx.doi.org/10.1063/1.2132270

[24] Commission of the European Communities, CEC (1990) Commission Recommendation of 1990 on the Protection of the Public against Indoor Exposure to Radon. European Community, L80, 26-28.

[25] ICRP-50 (1987) Lung Cancer Risk from Indoor Exposures to Radon Daughters. Pergamon Press, Oxford.

[26] ICRP International Commission on Radiological Protection (1981) Limits for Inhalation of Radon Daughters by Workers. Annals of the ICRP, 6, 1-24.

[27] UNSCEAR (1988) Sources, Effects and Risks of Ionizing Radiation. United Nations, New York.

[28] Abbady, A. and Michel, R. (2004) Indoor Radon Measurement with the Lucas Cell Technique. Applied Radiation and Isotopes, 61, 1469-1475. http://dx.doi.org/10.1016/j.apradiso.2004.03.065

[29] ICRP-60 (1990) Radiation Protection Recommendations of the International Commission on Radiological Protection. Pergamon Press, Oxford.

[30] Othman, I., Hushari, M., Raja, G. and Alsawaf, A. (1996) Radon in Syrian Houses. Journal of Radiological Protection, 16, 45-50. http://dx.doi.org/10.1088/0952-4746/16/1/006

[31] Bem, H., Dománski, T., Bakir, Y.Y. and Alzenki, S. (1996) Radon Survey in Kuwait Houses. In: IRPA9, 1996 International Congress on Radiation Protection, 2, IRPA, Vienna, 14-19 April 1996, 101-103.

[32] Sohrabi, M. and Solaymanian, A.R. (1988) Indoor Radon Level Measurements in Iran Using AEOI Passive Dosimeters. In: Radiation Protection Practice. Proceedings of the 7th International Congress of the International Radiation Protection Association, 1, Pergamon Press, Sydney, 242-245.

[33] Cherouati, D.E. and Djeffal, S. (1988) Measurements of Radon and Radon Daughters in Dwellings in Algiers. Radiation Protection Dosimetry, 25, 137-139.

[34] Kenawy, M.A. and Morsy, A.A. (1991) Measurements of Environmental Radon-222 Concentration in Indoor and Outdoors in Egypt. International Journal of Radiation Applications and Instrumentation. Part D. Nuclear Tracks and Radiation Measurements, 19, 343-345. http://dx.doi.org/10.1016/1359-0189(91)90210-9

[35] Létourneau, E.G., McGregor, R.G. and Walker, W.B. (1984) Design and Interpretation of Large Surveys for Indoor Exposure to Radon Daughters. Radiation Protection Dosimetry, 7, 303-308.

[36] Marcinowski, F. (1992) Nationwide Survey of Residential Radon Levels in the US. Radiation Protection Dosimetry, 45, 419-424.

[37] Gomez, J.C., Oliveira, A.A., Arnaud, M.I. and Ciallella, H.E. (1993) Radon in Dwellings in Argentina. Proceedings of the International Conference on High Levels of Natural Radiation, Ramsar, 3-7 November 1990, 391-400.

[38] Stuardo, E. (1996) Natural Radiation Measurements in Chile. Radiation Protection Dosimetry, 67, 129-133. http://dx.doi.org/10.1093/oxfordjournals.rpd.a031804

[39] Zuoyuan, W. (1992) Natural Radiation in China: Level and Distribution. Laboratory of Industrial Hygiene, Beijing.

[40] Tso, M.W. and Leung, J.K.C. (1991) Survey of Indoor ${ }^{222}$ Rnconcentrations in Hong Kong. Health Physics, 60, $237-$ 241. http://dx.doi.org/10.1097/00004032-199102000-00012

[41] Subba Ramu, M.C., Shaikh, A.N., Muraleedharan, T.S., et al. (1991) Environmental Radon Monitoring in India and a Plea for a National Effort. Conference on Particle Tracks in Solids, Jodhpur, 9-11 October 1991, 11.

[42] Fujimoto, K., Kobayashi, S., Uchiyama, M., Doi, M. and Nakamura, Y. (1997) Nationwide Indoor Radon Survey in Japan. Hoken Butsuri, 32, 41-51. http://dx.doi.org/10.5453/jhps.32.41 
[43] Pahapill, L., Rulkov, A. and Swedjemark, G.A. (1996) Radon in Estonian Buildings. Establishment of a Measurement System and Obtained Results. SSI-Rapport 96:13.

[44] Biernacka, M., Henschke, J., Jagielak, J., et al. (1992) Preliminary Measurements of the Natural Ionizing Radiation in Three Types of Buildings in Poland. Progress of Medical Physics, 26, 55-66.

[45] Arvela, H., Mäkeläinen, I. and Castrén, O. (1993) Residential Radon Survey in Finland. STUK-A108.

[46] Wrixon, A.D., Green, B.M.R., Lomas, P.R., et al. (1988) Natural Radiation Exposure in UK Dwellings. NRPB-R190.

[47] Christofides, S. and Christodoulides, G. (1993) Airborne ${ }^{222}$ Rn Concentration in Cypriot Houses. Health Physics, 64, 392-396. http://dx.doi.org/10.1097/00004032-199304000-00006

[48] Georgiou, E., Ntalles, K., Molfetas, M., Athanassiadis, A. and Proukakis, C. (1988) Radon Measurements in Greece. In: Radiation Protection Practice. Proceedings of the 7th International Congress of the International Radiation Protection Association, 1, Pergamon Press, Sydney, 387-390.

[49] Faísca, M.C., Teixeira, M.M.G. and Bettencourt, A.O. (1992) Indoor Radon Concentrations in Portugal—A National Survey. Radiation Protection Dosimetry, 45, 465-467.

[50] Thomas, J. (1991) A Review of Surveys of Indoor Radon Measurements in Czechoslovakia. In: Radon Investigations in Czechoslovakia II, Geological Survey, Prague, 1-12.

[51] Nikl, I. (1996) The Radon Concentration and Absorbed Dose Rate in Hungarian Dwellings. Radiation Protection Dosimetry, 67, 225-228. http://dx.doi.org/10.1093/oxfordjournals.rpd.a031821

[52] Langroo, M.K., Wise, K.N., Duggleby, J.G. and Kotler, L.H. (1991) A Nationwide Survey of Radon and Gamma Radiation Levels in Australian Homes. Health Physics, 61, 753-761.

[53] Robertson, M.K., Randle, M.W. and Tucker, L.J. (1988) Natural Radiation in New Zealand Houses. NRL 1988/6.

[54] United Nations Scientific Committee on the Effects of Atomic Radiation (2000) Annex B. UNSCEAR Report to the General Assembly. 1, United Nations, New York. 
Scientific Research Publishing (SCIRP) is one of the largest Open Access journal publishers. It is currently publishing more than 200 open access, online, peer-reviewed journals covering a wide range of academic disciplines. SCIRP serves the worldwide academic communities and contributes to the progress and application of science with its publication.

Other selected journals from SCIRP are listed as below. Submit your manuscript to us via either submit@scirp.org or Online Submission Portal.
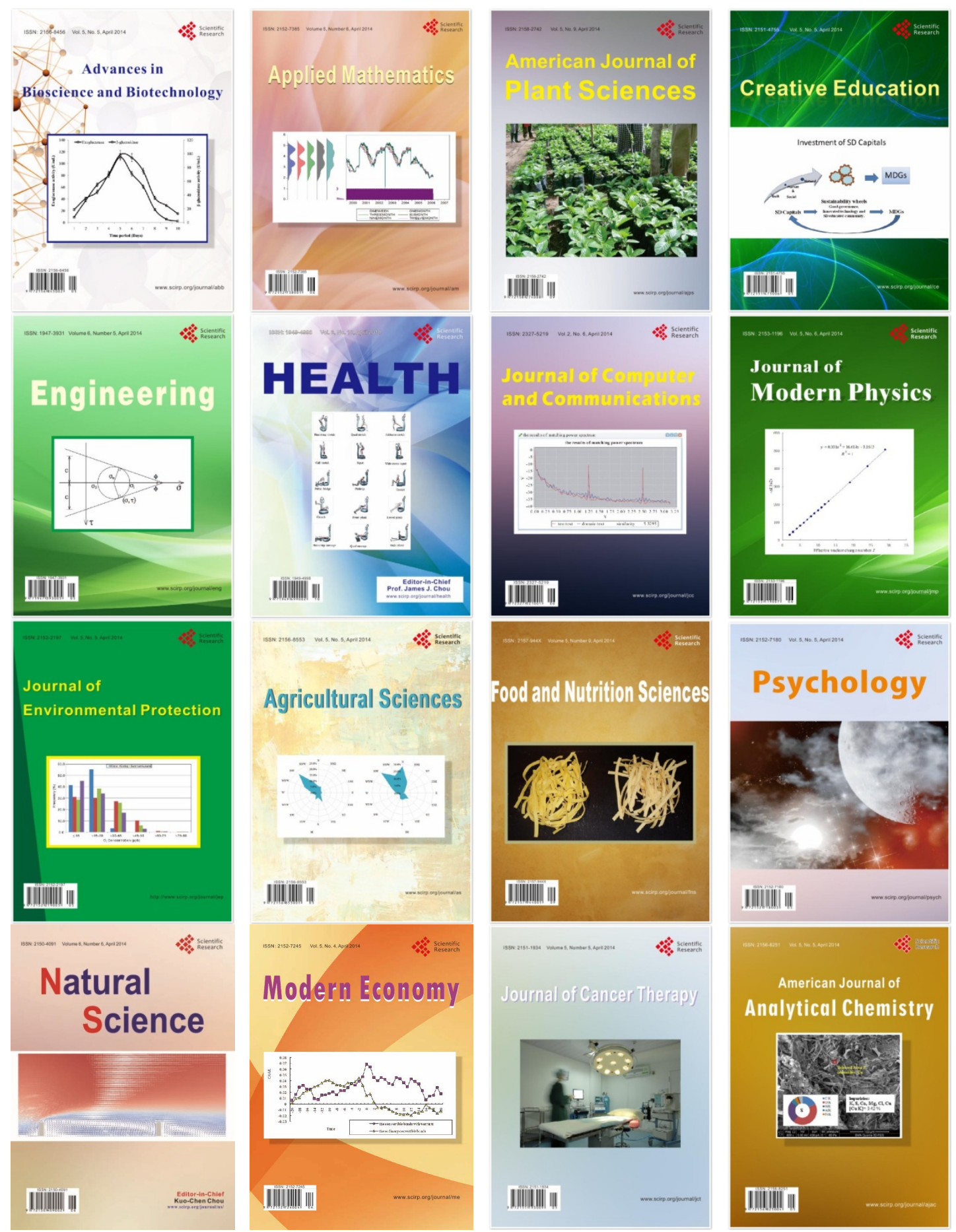